\title{
CORROSION BEHAVIOR STUDY OF STEEL POLE IN DIFFERENT COATING TECHNOLOGY
}

\author{
Nurul Shuhada Pauzai \\ Asset Performance Unit \\ TNB Research, Kajang, Selangor, Malaysia \\ Khairuddin Abdullah \\ Asset Performance Unit \\ TNB Research, Kajang, Selangor, Malaysia
}

\author{
Nor Diana Ruszaini Mohd Zin \\ Asset Performance Unit \\ TNB Research, Kajang, Selangor, Malaysia \\ Mithila Seva Bala Sundaram \\ Asset Performance Unit \\ TNB Research, Kajang, Selangor, Malaysia
}

\author{
Mohd Hafiz Mat Daud \\ Asset Performance Unit \\ TNB Research, Kajang, Selangor, Malaysia
}

\begin{abstract}
Corrosion of steel pole is a serious issue as they used steel pole to support overhead power line in distribution. A lot of money and time are spent for maintenance and repair of existing steel pole. This paper presents investigation on various coating technologies of steel pole for initial corrosion activity. Five types of coating were used on steel samples; epoxy, VEF polyglass, galvanized, epoxy galvanized and polyglass galvanized. The accelerated ageing test, salt spray test and water absorption test were used to determine coating degradation and severity of corrosion process. It was found that, the corrosion rate for epoxy galvanized and VEF polyglass galvanized were higher as the samples were undergoing accelerated ageing test. While VEF polyglass steel showed higher percentage of weight loss during salt spray test. In addition, the results of water absorption behavior showed that epoxy steel gave higher average of absorption rate. The results obtained lead to low degradation of coating as the corrosion rate seem to be uniform
\end{abstract}

Keywords - Corrosion rate, degradation, coating, steel, testing

\section{INTRODUCTION}

IN the distribution sector, energy utilities used various types of pole to support overhead power lines and their accessories which carry low voltage power to distribute the power to customers. Most of the energy utilities used steel poles to carry the load power as steel pole gives more benefits over wood pole [1]. Thus, the design of steel pole must be long life, high strength, relatively light weight, low maintenance cost and environmentally friendly [2]. However, steel is prone to rust and corrosion of steel poles become critical damaging problem as the corrosion activity is reduced mechanical strength and affect performance of steel poles. Besides, rusting or corrosion process caused the poles surface to become unsightly. There are many reasons and environmental factors influence the corrosion of poles, such as temperature, $\mathrm{pH}$ (level of acidity and alkaline) and salinity. Corrosion activity due to environmental factors are difficult to control. The corrosion process is take place as electrochemical reaction at the metal interface occur with presence of water, oxygen, and corrosion ion (Cl- and F-) [3]. Furthermore, the process will be accelerated as the acidic gases such as carbon dioxide, carbon monoxide and sulphur dioxide are combine between the chemical reaction [4]. Hence, for these reasons the steel poles are protected by various corrosion protection methods. For example, by using decreasing potential (cathodic protection and lowering oxidant concentration), increasing oxidation potential (anodic protection and oxidising additives), increasing $\mathrm{pH}$, separating metal (metallic, paint and organic coatings) or alternatively use of alloys [5]. In this paper, five technologies of pole coating are used to act as steel protection. The coating technologies are epoxy, VEF polyglass, galvanised, epoxy galvanised, and VEF polyglass galvanised are used as steel poles protection.

Epoxy steel coating is a coating compound consists of two elements, which are epoxy resin and polyamine hardener as a catalyst. When both of these elements are mixed in chemical reaction, it creates cross-linked between the elements. Thus, when the epoxy coating is fully cured, it produced excellent mechanical properties such as hardness, durability, abrasion, and chemical resistance. Epoxy coating is widely used in marine as protection of metallic materials from corrosion activity due to high efficiency in seawater [6]. Epoxy coating have good mechanical properties as it has high density of cross-linked, well adhesion to metal substances [7], good in acidic solution approach up to $97 \%$ efficiency [8], good 
chemical and corrosion resistance [9], flame retardant additives [10] and long-lasting layer of protection. The structure of epoxy is brittle but by chemical modification and additional of thermoplastic and inorganic phases this limitation could be overcome [11]. While galvanised steel coating, is a zinc protective layer on steel to prevent corrosion activity to occur. Galvanisation of steel results in formation of metallic bond of zinc with steel substrate which gives high integrity of coating. The galvanisation of steel provides double protection to the steel surface, as the zinc forms a compact oxide layer on its surface and acted as barrier protection. In corrosion process, zinc will sacrifice itself and provides cathodic protection to the steel pole [12]. The galvanised steel is widely used in application such as construction, utilities, transport infrastructures and so on. Usually, hot-dip galvanizing method is used as the process is simple and provide long term corrosion protection on steelwork. Besides that, it is a cost-effective method. During the process, a metallurgical bonded coating is created to protect the steel for both external and internal within hollow sections from harsh environments. Galvanised steel has been used as its beautiful appearance, good corrosion resistance, good mechanical properties and acted as sacrificial coating [13,14]. However, in normal industry environment corrosion of zinc is 25 times slower than steel even though zinc is more electronegative than iron [15]. The lifespan and durability of galvanised coating is depend on thickness of zinc coating deposited on the steel surface. Therefore, due to meet minimum weight prescribed in standards and economize the production cost, the thickness of zinc coating is reduced [16]. Hence, after exposed to rugged environments the galvanised is inherently more active and prone to corrosion. Next, VEF polyglass is vinyl ester or acrylic co-polymer loaded with flake glass and reinforced with fibre. Usually this coating is applied direct on the wet surface by spray application, after surface preparation is done. This coating technology has excellent resistance for demineralised water and good resistance to many solvents. Besides, VEF polyglass is potable water application. Therefore, in this study accelerated ageing test, salt spray test, and water absorption test are performed to simulate relative performance of steel pole coating technologies and corrosion severity due to corrosion activity.

\section{MATERIAL AND METHODS}

\section{A. Material -}

In this testing, the study samples are uncoated steel pole as reference, epoxy steel pole, VEF polyglass steel pole, galvanized pole, epoxy galvanized pole and polyglass galvanized pole. Each sample are labelled as in Table 1. The tested pole samples are cut in rectangular shape with $101.35 \mathrm{~mm}$ length and $25.10 \mathrm{~mm}$ width as shown in Fig 1 . Table 2 is show chemical composition of coating for each sample.
Table -1 Tested samples

\begin{tabular}{|c|c|}
\hline Sample & Type of sample \\
\hline Sample A & Steel pole \\
\hline Sample B & Epoxy steel pole \\
\hline Sample C & VEF polyglass steel \\
\hline Sample D & Galvanised pole \\
\hline Sample E & Epoxy galvanised pole \\
\hline Sample F & VEF polyglass galvanised pole \\
\hline
\end{tabular}

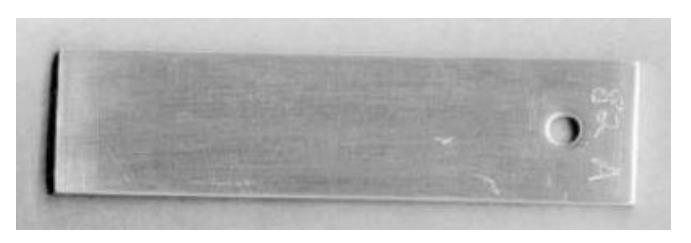

Fig. 1.Coupon size for testing sample

Table -2 Chemical composition of each sample

\begin{tabular}{|c|c|c|}
\hline Material (\%) & $\mathrm{Mn}$ & $\mathrm{Fe}$ \\
\cline { 2 - 3 } Sample A & 1.03 & 98.36 \\
\hline
\end{tabular}

\begin{tabular}{|c|c|c|c|c|c|c|}
\hline \multirow{3}{*}{ Material (\%) } & $\mathrm{Ti}$ & $\mathrm{V}$ & $\mathrm{Cr}$ & $\mathrm{Mn}$ & $\mathrm{Fe}$ & $\mathrm{Co}$ \\
\cline { 2 - 7 } Sample B & 30.91 & 0.664 & 0.089 & 0.5 & 66.07 & 1.2 \\
\cline { 2 - 7 } & $\mathrm{Cu}$ & $\mathrm{Ni}$ & $\mathrm{Zn}$ & $\mathrm{Zr}$ & $\mathrm{Nb}$ & $\mathrm{Mo}$ \\
\cline { 2 - 7 } & 0.226 & 0.183 & 0.056 & 0.046 & 0.009 & 0.008 \\
\hline
\end{tabular}

\begin{tabular}{|c|c|c|c|c|c|c|}
\hline \multirow{3}{*}{ Material (\%) } & $\mathrm{Ti}$ & $\mathrm{V}$ & $\mathrm{Mn}$ & $\mathrm{Fe}$ & $\mathrm{Co}$ & $\mathrm{Ti}$ \\
\cline { 2 - 7 } Sample C & 38.27 & 0.808 & 0.403 & 52.24 & 1.8 & 38.27 \\
\cline { 2 - 7 } & $\mathrm{Cu}$ & $\mathrm{Zn}$ & $\mathrm{Zr}$ & $\mathrm{Nb}$ & $\mathrm{Mo}$ & $\mathrm{Cu}$ \\
\cline { 2 - 7 } & 0.226 & 6.03 & 0.046 & 0.013 & 0.014 & 0.226 \\
\hline
\end{tabular}

\begin{tabular}{|c|c|c|}
\hline Material (\%) & Zn & Fe \\
\cline { 2 - 3 } Sample D & 99.01 & 0.75 \\
\hline
\end{tabular}

\begin{tabular}{|c|c|c|c|c|c|}
\hline \multirow{3}{*}{$\begin{array}{c}\text { Material (\%) } \\
\text { Sample E }\end{array}$} & $\mathrm{Ti}$ & $\mathrm{V}$ & $\mathrm{Mn}$ & $\mathrm{Fe}$ & $\mathrm{Co}$ \\
\cline { 2 - 6 } & 38.27 & 0.808 & 0.403 & 52.24 & 1.8 \\
\cline { 2 - 6 } & $\mathrm{Cu}$ & $\mathrm{Zn}$ & $\mathrm{Zr}$ & $\mathrm{Nb}$ & $\mathrm{Mo}$ \\
\cline { 2 - 6 } & 0.226 & 6.03 & 0.046 & 0.013 & 0.014 \\
\hline
\end{tabular}

\begin{tabular}{|c|c|c|c|c|c|c|}
\hline Material (\%) & $\mathrm{Ti}$ & $\mathrm{V}$ & $\mathrm{Fe}$ & $\mathrm{Zn}$ & $\mathrm{Zr}$ & $\mathrm{W}$ \\
\cline { 2 - 7 } Sample F & 29.2 & 0.404 & 0.781 & 64.22 & 0.025 & 5.22 \\
\hline
\end{tabular}

\section{B. Accelerated Aging Test -}

The accelerated aging test consists of the following cycle, in the beginning the samples are exposed to 8 hours at $60{ }^{\circ} \mathrm{C}$ $\left( \pm 2.5^{\circ} \mathrm{C}\right)$ to ultraviolet $(\mathrm{UV})$ radiation in a modified commercial QUV Accelerated Weathering Tester as show in Fig 2 [17]. For solar reflectors the lamp type UVA-340 is used. The lamps emit radiation in short wavelength-range of 295 to $365 \mathrm{~nm}$ with peak emission is at $340 \mathrm{~nm}$. The radiation of UV emitted by UVA-340 lamps are almost same to natural sunlight as the spectral power distribution (SPD) of UVA-340 is very close to sunlight (see Fig 3). After that, the samples are 


\section{International Journal of Engineering Applied Sciences and Technology, 2021 \\ Vol. 5, Issue 9, ISSN No. 2455-2143, Pages 58-65 \\ Published Online January 2021 in IJEAST (http://www.ijeast.com)}

exposed to 4 hours at $50{ }^{\circ} \mathrm{C}\left( \pm 2.5^{\circ} \mathrm{C}\right)$ to condensation $(100 \%$ relative humidity with $1.55 \mathrm{~W} / \mathrm{m} 2 / \mathrm{nm}$ irradiation) [18]. The total duration of one cycle is 12 hours (see Fig 4). Thus, in this work the samples are exposed to control environment based on American Society of Testing and Materials (ASTM) D589496 and ASTM D4587 as shown in Table 3. The testing is run for 1,968 hours.

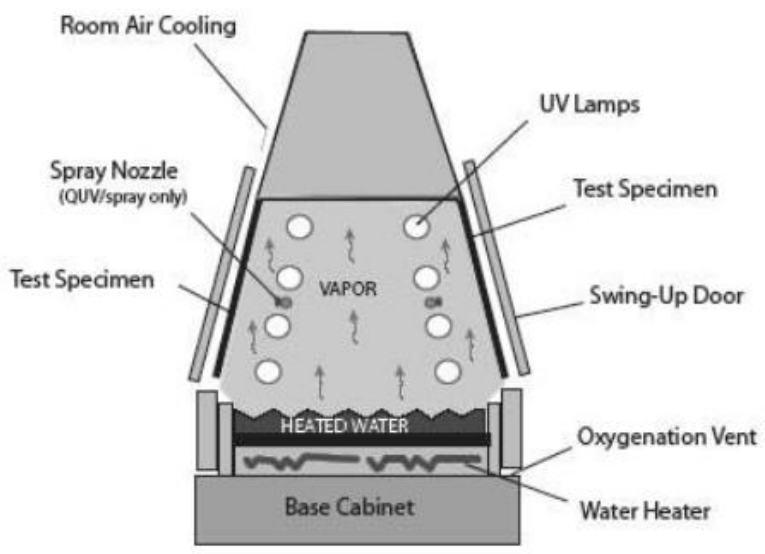

Fig. 2. QUV Accelerated Weathering chamber [17]

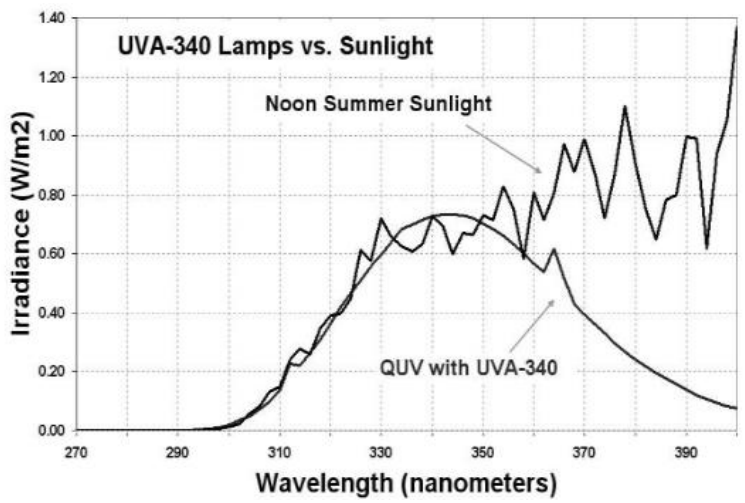

Fig. 3. UVA-340 lamps against sunlight [17]

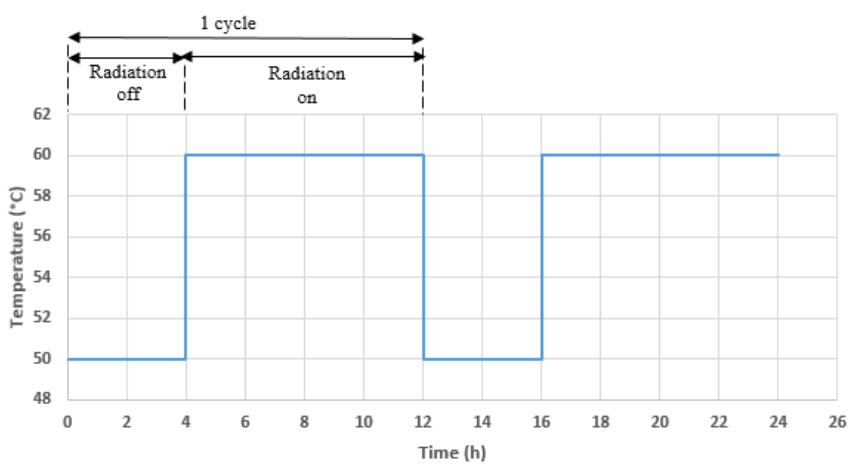

Fig. 4. Accelerated aging testing cycle

Table -3 Experiment result

\begin{tabular}{|c|c|}
\hline Exposed condition & Condition level \\
\hline Irradiance & $1.55 \mathrm{~W} / \mathrm{m}^{2} / \mathrm{nm}$ \\
\hline Wavelength & $340 \mathrm{~nm}$ \\
\hline Exposed cycle & $\begin{array}{l}\text { Refer Cycle } 4 \text { based on ASTM D } 4587 \\
8 \text { hours of UV at } 60( \pm 2.5){ }^{\circ} \mathrm{C} \text {, black panel } \\
\text { temperature } \\
4 \text { hours of condensation at } 50( \pm 2.5){ }^{\circ} \mathrm{C} \text {, black } \\
\text { panel temperature } \\
\text { Repeated continuously }\end{array}$ \\
\hline
\end{tabular}

\section{Salt Spray Test -}

The samples are tested according to ASTM B117 and this standard is widely used for salt spray testing. The samples are placed in enclosed chamber and exposed to continuous indirect of salt water solution at rate 1.0 to $2.0 \mathrm{ml} / \mathrm{h}$ on a surface of $80 \mathrm{~cm}^{2}$ [19]. The chamber condition is set to $35^{\circ} \mathrm{C}$ with a spray of sodium chloride $(\mathrm{NaCl})$ solution by ratio of $5 \%$ sodium chloride and $95 \%$ of pure water, by weight. The $\mathrm{pH}$ of the salt solution is maintained at 6.5 to 7.2 which is used in NSS test (Neutral Salt Spray). The chamber climate is maintained under constant steady state condition and the test duration is variable, as show in table 4 .

Table -4 Test duration

\begin{tabular}{|c|c|}
\hline Batch & Duration \\
\hline First batch & 180 days \\
\hline Second batch & 360 day \\
\hline Third batch & 540 days \\
\hline
\end{tabular}

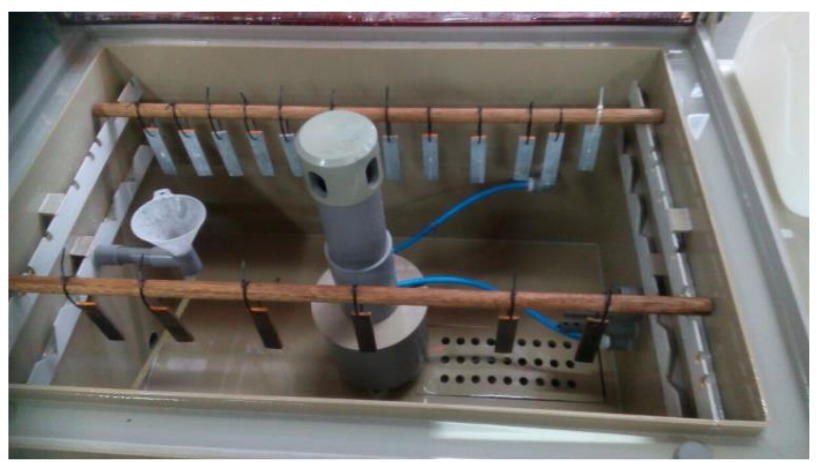

Fig. 5.Salt spray test

\section{Water Absorption Test -}

The water absorption test is conducted according to ASTM D570 to determine the amount of water absorbed by coated steel samples under specified conditions. The factors that influenced this testing are type of plastic, additives used, temperature and duration of exposure. The results obtained are represent the performance of the coating materials in water or humid environments. The samples were prepared by cutting into small rectangle shape with $50 \mathrm{~mm}$ diameter with 5 to 10 $\mathrm{mm}$ thick. The coating samples are initially dried in an oven for a specified time and temperature, and then placed in a desiccator to cool. In this method, the coating samples in 
initial dry weight are weighted. Next, the samples are immersed in a bath of distilled water at $23{ }^{\circ} \mathrm{C}$ and the duration of absorption as tabulated in Table 4. Each sample was removed from the water, wiped dry with a lint free cloth, and weighted again.

\section{RESUlT AND DisCUSSION}

\section{A. Accelerated Aging Test -}

The different tests are performed to reproduce the observed degradation of steel pole coatings. By visual observation (see Fig 5), the uncoated steel pole is show signs of degradation while the other samples are still in good condition. The corrosion activity of the coated steel pole is still low as the samples are exposed to 1,968 hours in simulated outdoor condition. Therefore, coating thickness and corrosion thickness of each sample are measured to check the severity of corrosion. The coating thickness and corrosion thickness are measured by using ElektroPhysik coating thickness sensor and DM5E corrosion thickness gauge. Table 5 show the coating and corrosion thickness, while Table 6 show the weight of each sample before and after the test.

After the samples are stressed with simulated environment, it seems that the coating thickness of galvanised poles with coating of epoxy and VEF polyglass (Sample E and F) are increased to $3.39 \%$ and $0.95 \%$. Same as galvanised pole (Sample D), the thickness is higher up to $0.95 \%$. Inversely to steel poles, the coating thickness are decreased by $-1.90 \%$ and $0.33 \%$ for epoxy and VEF polyglass (Sample B and C). The results show that the pattern of corrosion thickness and coating thickness are seem to be same. This indicate that, the corrosion thickness for galvanised poles with epoxy and VEF polyglass (Sample E and F) are increased to $21.21 \%$ and $12.35 \%$. While steel pole coated with epoxy and VEF polyglass (Sample B and C) are decreased by $-17.08 \%$ and $-4.69 \%$. Nevertheless, as predicted the corrosion activity on sample $\mathrm{A}$ is actively occur due to original uncoated steel. The corrosion thickness seems to be high at $17.14 \%$. While for galvanised pole, the corrosion thickness is slightly reduced to $-0.58 \%$. In addition, the data show in table 5 is consistence to the measured data in table 6.

Table -5 Coating and corrosion thickness for different technology

\begin{tabular}{|c|c|c|c|c|c|c|}
\hline \multirow[b]{2}{*}{ 岂 } & \multicolumn{3}{|c|}{ Coating thickness $(\mu \mathrm{m})$} & \multicolumn{3}{|c|}{ Corrosion thickness (mm) } \\
\hline & 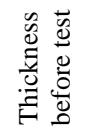 & 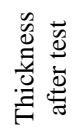 & 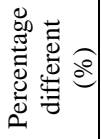 & 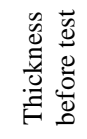 & 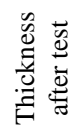 & 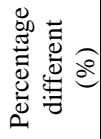 \\
\hline Sample A & - & - & - & 5.25 & 6.15 & 17.14 \\
\hline Sample B & 5.53 & 5.43 & -1.90 & 7.26 & 6.02 & -17.08 \\
\hline Sample C & 5.46 & 5.44 & -0.33 & 5.97 & 5.69 & -4.69 \\
\hline Sample D & 4.90 & 4.95 & 0.98 & 5.13 & 5.10 & -0.58 \\
\hline Sample E & 5.14 & 5.31 & 3.39 & 4.95 & 6.00 & 21.21 \\
\hline Sample F & 5.17 & 5.22 & 0.95 & 5.10 & 5.73 & 12.35 \\
\hline
\end{tabular}

Table -6 Weight of tested samples

\begin{tabular}{|c|c|c|c|}
\hline Sample & $\begin{array}{c}\text { Weight before } \\
\text { test }(\mathrm{g})\end{array}$ & $\begin{array}{c}\text { Weight after } \\
\text { test }(\mathrm{g})\end{array}$ & $\begin{array}{c}\text { Percentage } \\
\text { different }(\%)\end{array}$ \\
\hline Sample A & 95.96 & 97.76 & 1.8 \\
\hline Sample B & 93.32 & 92.51 & -0.81 \\
\hline Sample C & 100.44 & 100.41 & -0.03 \\
\hline Sample D & 95.79 & 95.77 & -0.02 \\
\hline Sample E & 87.55 & 91.93 & 4.38 \\
\hline Sample F & 86.51 & 93.45 & 6.94 \\
\hline
\end{tabular}
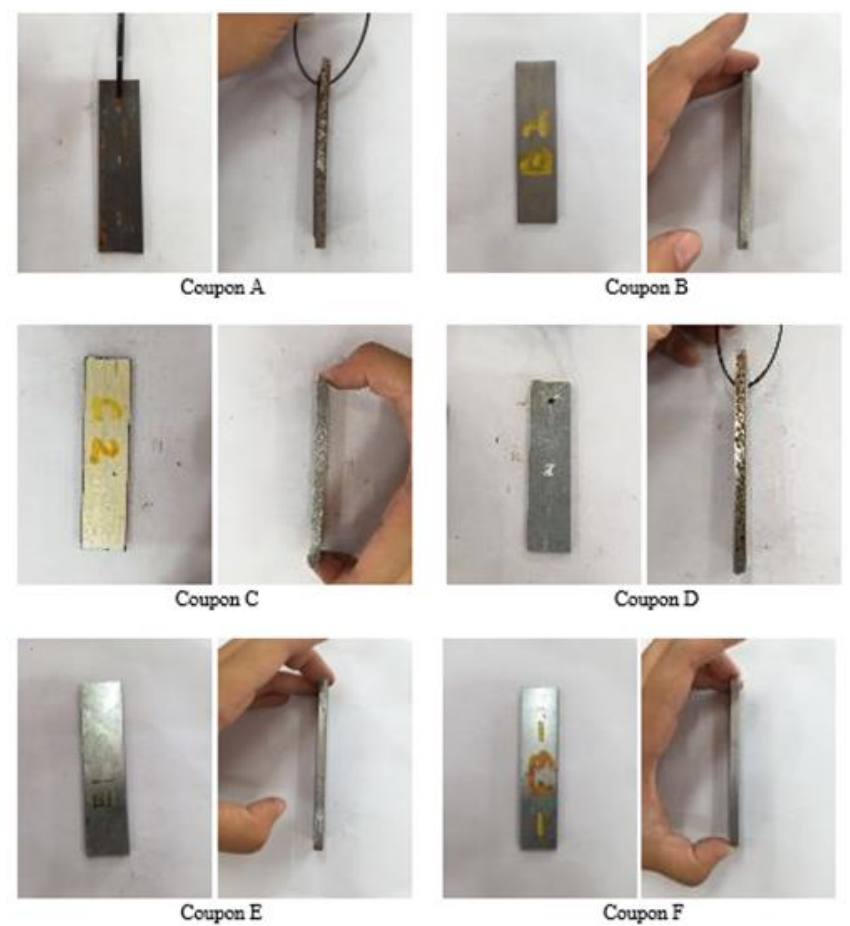

Fig. 6. Tested samples after undergo accelerated ageing life test

\section{B. Salt Spray Test -}

The salt spray test is used to evaluate corrosion process and coating degradation of each samples. The samples are tested in more realistic method by placed them in a controlled corrosive environment to produce relative corrosion information for each samples. The visual observation of corroded samples after 180 days in chamber is shown as Fig. 8. The effect of chloride was appeared on the six samples after the samples were tested for 180, 360 and 540 days. It can be seen that corrosion activity was aggressively occur at sample $\mathrm{A}$ as the color and physical condition of sample are changed. The sample A are heavily corroded as it is a bare steel. While for other samples, the rusting color is almost same as the corrosion activity seems to be uniform.

From the results, at 180 days the weight loss of tested samples was gaining weight as the chloride from salt spray was accumulated on the samples. Thus, it shows a negative value to 


\section{International Journal of Engineering Applied Sciences and Technology, 2021 \\ Vol. 5, Issue 9, ISSN No. 2455-2143, Pages 58-65 \\ Published Online January 2021 in IJEAST (http://www.ijeast.com)}

percentage loss, as show in table 7.1. This indicate that the samples are gain of weight. Then, for next cycle at 360 days, the samples have a weight loss in between $0.7 \%$ to $1.2 \%$. At this stage, acceleration of chemical reaction process was occurred due to presence of salt which acted as a catalyst to accelerate the corrosion process. From the table 7.2, sample F show the highest weight loss, $1.24 \%$ in this process while sample B show the lowest weight loss, which gave to $0.70 \%$ reduction of weight. As the duration was increased to 540 days, the layer of coating of samples tested were started to peel off. This process was indicated that more mass of the substrate element of the samples have fallen off due to weight loss up to $2.4 \%$.

Table -7.1 Weight of samples before and after salt spray test at 180 days

\begin{tabular}{|c|c|c|c|}
\hline Sample & Before $(\mathrm{g})$ & After $(\mathrm{g})$ & $\begin{array}{c}\text { Percentage of } \\
\text { Weight }(\%)\end{array}$ \\
\hline Sample A & 97.52 & 97.82 & -0.31 \\
\hline Sample B & 97.08 & 97.49 & -0.42 \\
\hline Sample C & 106.21 & 106.6 & -0.37 \\
\hline Sample D & 94.23 & 94.93 & -0.74 \\
\hline Sample E & 92.71 & 92.82 & -0.12 \\
\hline Sample F & 95.06 & 95.31 & -0.26 \\
\hline
\end{tabular}

Table -7.2 Weight of samples before and after salt spray test at 360 days

\begin{tabular}{|c|c|c|c|}
\hline Sample & Before $(\mathrm{g})$ & After $(\mathrm{g})$ & $\begin{array}{c}\text { Percentage of } \\
\text { Weight }(\%)\end{array}$ \\
\hline Sample A & 97.99 & 96.92 & 1.09 \\
\hline Sample B & 98.22 & 97.53 & 0.70 \\
\hline Sample C & 100.69 & 99.75 & 0.93 \\
\hline Sample D & 97.24 & 96.18 & 1.09 \\
\hline Sample E & 100 & 99.27 & 0.73 \\
\hline Sample F & 93.69 & 92.53 & 1.24 \\
\hline
\end{tabular}

Table -7.3 Weight of samples before and after salt spray test at 520 days

\begin{tabular}{|c|c|c|c|}
\hline Sample & Before $(\mathrm{g})$ & After $(\mathrm{g})$ & $\begin{array}{c}\text { Percentage of } \\
\text { Weight }(\%)\end{array}$ \\
\hline Sample A & 97.55 & 96.16 & 1.42 \\
\hline Sample B & 92.71 & 91.59 & 1.21 \\
\hline Sample C & 100.64 & 98.21 & 2.41 \\
\hline Sample D & 95.94 & 94.79 & 1.20 \\
\hline Sample E & 100 & 99.01 & 0.99 \\
\hline Sample F & 93.7 & 92.23 & 1.57 \\
\hline
\end{tabular}

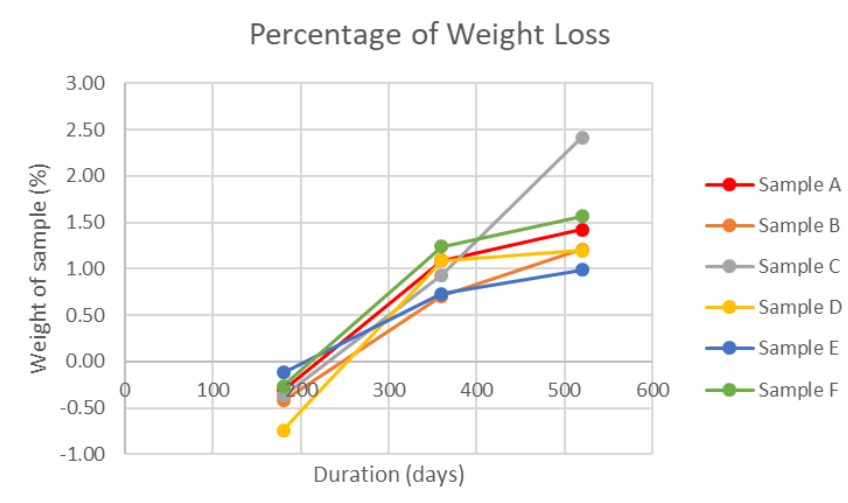

Fig. 7.Percentage of weight loss for 180,360 and 520 days

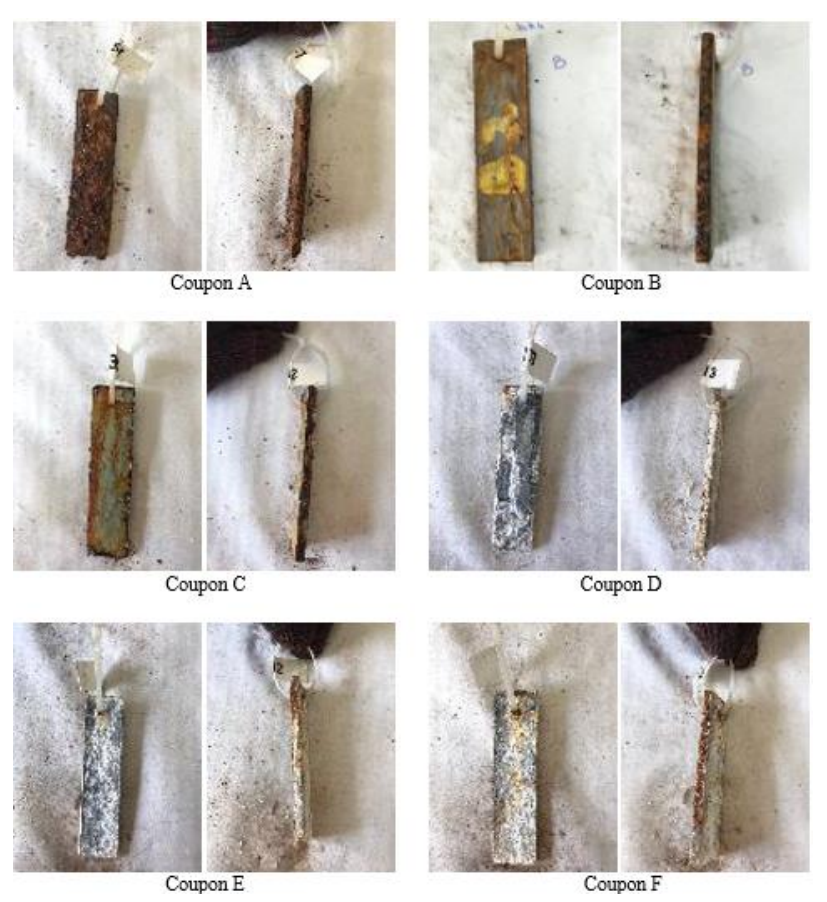

Fig. 8. Condition of each sample after undergo in salt spray chamber after 180 days

\section{Water Absorption Test-}

Water absorption test is conducted to determine amount of water absorbed by the steel pole coatings at specified conditions. The factors that affected the water absorption of pole coating layer are thickness of the coating layer, type of additive used, temperature of water, environment humidity and duration of sample exposure to water. The thickness of coating samples is 100 ums. In this study, the water absorption was measured by increased in weight percent. The formula used is [(Wet weight - Dry weight) / Dry weight] x 100. The absorption rates of each samples are shown in Table 8. 


\section{International Journal of Engineering Applied Sciences and Technology, 2021 \\ Vol. 5, Issue 9, ISSN No. 2455-2143, Pages 58-65 \\ Published Online January 2021 in IJEAST (http://www.ijeast.com)}

For this test, only four types of samples are measured as the sample A and sample D are not coated with any coating technology. From the graph, epoxy coating technology shows consistence results for steel pole (sample B) and galvanised pole (sample E). The trends for both samples are uniform, as the water absorption are decreasing ( $0.97 \%$ to $0.48 \%$ and $0.19 \%$ to $0.1 \%$ ) against exposure time (duration). Inversely for VEF polyglass coating technology, the trend are not consistence between sample $\mathrm{C}$ and sample $\mathrm{F}$. The trend of water absorption are increasing with maximum of $0.62 \%$ and $0.55 \%$ for steel pole (sample C) and galvanised pole (sample $\mathrm{F})$.

Table -8.1 Weight of samples before and after absorption test at 180 days

\begin{tabular}{|c|c|c|c|}
\hline Sample & Before $(\mathrm{g})$ & After $(\mathrm{g})$ & $\begin{array}{c}\text { Percentage of } \\
\text { Weight }(\%)\end{array}$ \\
\hline Sample B & 97.5 & 98.45 & 0.97 \\
\hline Sample C & 106.57 & 107.01 & 0.41 \\
\hline Sample E & 92.76 & 92.94 & 0.19 \\
\hline Sample F & 87.79 & 87.95 & 0.18 \\
\hline
\end{tabular}

Table -8.2 Weight of samples before and after absorption test at 360 days

\begin{tabular}{|c|c|c|c|}
\hline Sample & Before $(\mathrm{g})$ & After $(\mathrm{g})$ & $\begin{array}{c}\text { Percentage of } \\
\text { Weight }(\%)\end{array}$ \\
\hline Sample B & 95.26 & 95.65 & 0.41 \\
\hline Sample C & 102.75 & 103.09 & 0.33 \\
\hline Sample E & 86.95 & 87.05 & 0.12 \\
\hline Sample F & 94.48 & 95.17 & 0.73 \\
\hline
\end{tabular}

Table -8.3 Weight of samples before and after absorption test at 520 days

\begin{tabular}{|c|c|c|c|}
\hline Sample & Before (g) & After (g) & $\begin{array}{c}\text { Percentage of } \\
\text { Weight }(\%)\end{array}$ \\
\hline Sample B & 97.30 & 97.77 & 0.48 \\
\hline Sample C & 101.22 & 101.85 & 0.62 \\
\hline Sample E & 91.20 & 91.29 & 0.10 \\
\hline Sample F & 93.90 & 94.42 & 0.55 \\
\hline
\end{tabular}

Table -8.4 Summary of water absorption rate based on duration of exposure to water

\begin{tabular}{|c|c|c|c|c|}
\hline \multirow{2}{*}{$\begin{array}{c}\text { Duration } \\
\text { (days) }\end{array}$} & \multicolumn{4}{|c|}{ Water absorption rate (\%) } \\
\cline { 2 - 5 } & Sample B & Sample C & Sample E & Sample F \\
\hline 180 & 0.97 & 0.41 & 0.19 & 0.18 \\
\hline 360 & 0.41 & 0.33 & 0.12 & 0.73 \\
\hline 540 & 0.48 & 0.62 & 0.10 & 0.55 \\
\hline
\end{tabular}

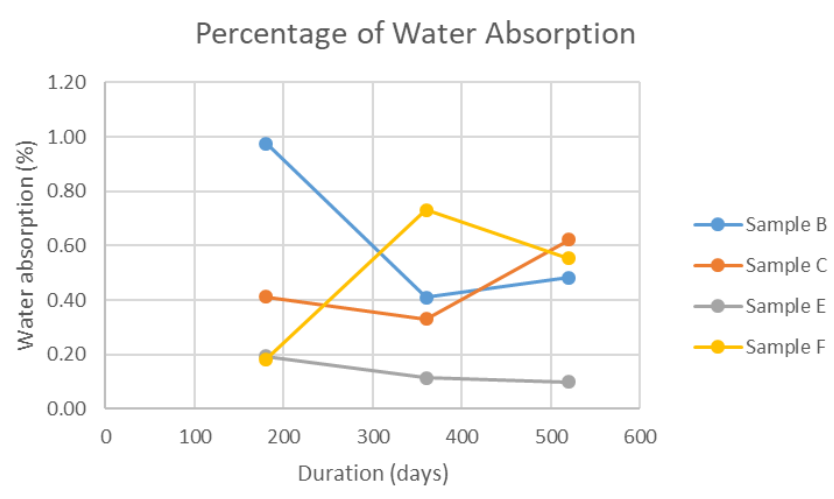

Fig. 9.Percentage of water absorption for 180, 360 and 520 days

\section{CONCLUSION}

Five types of coating technologies for steel pole was studied on corrosion behavior. The steel pole was coated with epoxy, VEF polyglass, galvanised, epoxy galvanised, and VEF polyglass galvanised. In this paper, the accelerated ageing test was conducted for 8 hours of UV at $60{ }^{\circ} \mathrm{C}$, and then 4 hours of condensation at $5060{ }^{\circ} \mathrm{C}$. This approach showed to lead to more realistic acceleration degradation for steel pole coating. The results showed the uncoated steel pole sample was heavily corroded, and only mild corrosion activity was occurred to the other samples. Hence, coating and corrosion thickness were measured to identify the severity of corrosion activity.

It was found that, the epoxy galvanised and polyglass galvanised poles showed a higher rate of corrosion activity as their weight and corrosion thickness are increased after the test. This indicated that formation of rust product. For example, a galvanic cell is formed as the zinc around the point of damage was corroded. The rusting products precipitate on the steel pole surface and the steel is protected because it is cathodic in relation to zinc (galvanised) coating. However, the epoxy steel and polyglass steel pole are corroded as the samples showed a weight loss and the corrosion thickness are seem to be actively reduced.

Then, the samples were placed in a closed chamber and expose to $\mathrm{NaCl}$ solution. The samples were tested up to 520 days. The weight of the samples was measured before and after the test. At first cycle, the samples showed a weight gain as the $\mathrm{NaCl}$ were accumulated on the samples. Then the samples have weight loss as the corrosion process were take part and the percentage of weight loss was between $0.73 \%$ to $1.24 \%$ at second cycle, and $1.0 \%$ to $2.4 \%$ at third cycle. VEF polyglass steel pole showed the highest weight loss followed by VEF polyglass galvanised pole. Next, the samples were immersed in water up to 540 days to identify the water absorption rate of coating technologies. The results showed that the epoxy coating of steel pole and galvanised pole gave a consistence absorption rate. The absorption rate of epoxy steel 


\section{International Journal of Engineering Applied Sciences and Technology, 2021 \\ Vol. 5, Issue 9, ISSN No. 2455-2143, Pages 58-65 \\ Published Online January 2021 in IJEAST (http://www.ijeast.com)}

pole is higher than epoxy galvanised pole. However, for VEF polyglass coating, the results are not consistence. At first cycle and third cycle, the VEF polyglass coating for steel pole showed higher rate than galvanised pole. However, at second cycle the results are vice versa.

\section{REFERENCE}

[1] R. E. Harness. (2000). Steel Distribution Poles and Their Environmental Implications, IEEE Industry Application Magazine, 2000, vol. 6, issues 3, (pp. 53 -56).

[2] B. Lacoursiere. (1999). Steel Utility Poles: Advantages and Applications, Rural Electric Power Conference, 1999, cat no: 99CH36302, (DOI No: 10.1109/REPCON.1999.768681).

[3] A.V. Radhamani, H.C. Lau, S. Ramakrishna. (2019). Nanocomposite Coatings On Steel For Enhancing The Corrosion Resistance: A Review, Journal of Composite Material, vol. 54, (pp. 681 - 701).

[4] Q. Tan, Z. Gao, J. Yan, D. Xia, W. Hu. (2020). Effect of Chloride Ions In Acid And Salt Solutions On SelfRepairing Ability And Corrosion Performance Of Titanium Dioxidefluorosiloxane Superhydrophobic Coating, Progress in Organic Coating, vol. 146, (DOI No: https://doi.org/10.1016/j.porgcoat.2020.105675).

[5] J. Yahalom. (2001). Corrosion Protection Methods, Encyclopaedia of Materials: Science and Technology (Second Edition), 2001, (pp. 1710 - 1713).

[6] N. Fredj, S. Cohendoz, X. Feagas, and S. Touzain. (2010). Some Consequences of Saline Solution Immersion On Mechanical Behaviour of Two Marine Epoxy-Based Coatings, Progress in Organic Coatings, 2010, Vol. 69, (pp. 82 - 91).

[7] J. Havlik, A. Kalendova, and D. Vesely. (2007). Electrochemical, Chemical and Barrier Action of Zinc Dust/Anticorrosive Pigments Containing Coatings, Journal Physics and Chemistry of Solids, 2007, Vol. 68, (pp. 1101 - 1105).

[8] T. Ziad, Khodaira, A. Anees, Khadomb, and H. A. Jasima. (2019). Corrosion Protection of Mild Steel in Different Aqueous Media Via Epoxy/Nanomaterial Coating: Preparation, Characterization and Mathematical Views, Journal of Materials Research and Technology (JMRT), 2019, vol. 8, issue 1, (pp. 424-435).

[9] O. R. Adetunji, O. O. Adegbesan, and I. K. Okediran. (2018). Protective Efficiency of Epoxy Resin Coating On Mild Steel Plate in $\mathrm{HCl}, \mathrm{NaOH}$ and Distilled Water Media, Umudike Journal of Engineering and Technology (UJET), 2018, Vol. 4, no. 2, (pp. 52 - 56).

[10] D. E. Weil. (2011). Fire-Protective and Flame-Retardant Coatings - A State of The Art Review, Journal Fire Science, 2011, vol. 29, (pp. 259-96).
[11] T. Hobbiebrunken, B. Fiedler, M. Hojo, S. Ochaiai and K. Schulte. (2005). Microscopic Yielding of CF/Epoxy Composites and The Effect On The Formation Of Thermal Residual Stresses," Composite Science and Technology, 2005, Vol. 65, (pp. 1626 - 1635).

[12] A. Al-Negheimish, R. R. Hussain, A. Alhozaimy, and D.D.N. Singh. (2020). Corrosion Performance of Hot-Dip Galvanized Zinc-Aluminum Coated Steel Rebars in Comparison to The Conventional Pure Zinc Coated Rebars in Concrete Environment, Construction and Building Materials, vol 24, (DOI No: https://doi.org/10.1016/j.conbuildmat.2020.121921)

[13] P. R. Edavan and R. Kopinski. (2009). Corrosion Resistance of Painted Zinc Alloy Coated Steels, Corrosion Science, 2009, vol. 51, (pp. 2429 - 2442).

[14]C. Li, M Ruina, A. Du, Y. Fan, X. Zhao and X. Cao. (2019). One-Step Fabrication of Bionic Superhydrophobic Coating On Galvanised Steel with Excellent Corrosion Resistance, Journal of Alloys and Compounds, 2019, (pp. 272 - 283).

[15] N.R. Short, S. Zhou, J.K. Dennis. (1996). Electrochemical Studies on The Corrosion of A Range of Zinc Alloy Coated Steel In Alkaline Solutions, Surface and Coatings Technology, vol. 79, (pp. 218 - 224).

[16] S. Paswan, J. K. Singh, D.D.N. Singh (2020). Effect of Lead Alloying on Corrosion Characteristics of Galvanized Coatings Exposed in Atmosphere, Simulated Laboratory and A Service Environment, Surfaces and Interfaces, vol. 21, (DOI No: https://doi.org/10.1016/j.surfin.2020.100752).

[17] J. Quill and OH. S Fowler, "The essentials of laboratory weathering," unpublished.

[18] Standard Practice for Fluorescent UV-Condensation Exposures of Paint and Related Coatings, ASTM D458711, 2011.

[19] Corrosion Tests in Artificial Atmosphere - Salt spray test, ISO 9227, 2006.

[20] T. Miwa, Y. Takeshita, A. Ishii and T. Sawada. (2018). Simulation of Water Absorption and Desorption Behavior for Anti-Corrosion Coatings in Existing and New Accelerated Corrosion Test," Progress in Organic Coatings, 2018, (pp. 711 - 78).

[21] Standard Practice for Cyclic Salt Fog/UV Exposure of Painted Metal, (Alternating Exposures in a Fog/Dry Cabinet and a UV/Condensation Cabinet), ASTM D589496, 2016.

[22] F. Sutter, A. Fernandez-Garcia, J. Wette and P. Heller. (2014). Comparison and Evaluation Accelerated Ageing Tests for Reflectors, Energy Procedia, 2014, (pp. $1718-$ 1727).

[23] N. Fredj, S. Cohendoz, X. Feagas, and S. Touzain. (2010). Some Consequences of Saline Solution Immersion On 
Mechanical Behavior of Two Marine Epoxy-Based Coatings, Progress in Organic Coatings, 2010, Vol. 69, (pp. 82-91).

[24] Lopez, P.S Leung and F. Inam. (2016). Mechanical Characterization of Protective Coating for Offshore Wind Turbine Towers and Transition Pieces", International Conference for Students on Applied Engineering (ICSAE), 2016, (DOI 10.1109/ICSAE.2016.7810207).

[25] A. Mallik and C. Char. (2012). Silicon Effect Color Transformation On Galvanized Steel Lattice Towers, PES Transmission and Distribution Conference, August 2012, (DOI no: 10.1109/TDC.2012.6281581).

[26] L. Jian, W. Jianxin, L. Zengli, L. Wei, W. Sen and L. Zhizhong. (2010). Robust Planning of Test Poles for Grounding Grids Corrosion Diagnosis," International Conference on Measuring Technology and Mechatronic Automation, May 2010, Vol 3, (DOI No: 10.1109/ICMTMA.2010.723).

[27] K. Tsukada, T. Tomioko, S. Wakabayashi, K. Sakai, and T. Kiwa. (2018). Magnetic Detection of Steel Corrosion at A Buried Position Near, IEEE Transactions on Magnetics, November 2018, Vol. 54, no. 11, (DOI No: 10.1109/TMAG.2018.2833852).

[28] H. M. Yousif, W. M. Salih, N. J. A. Kader, and P. S. Ahmed. (2017). Comparison Study Between Hot Dip Galvanizing Steel and Coated Steel Used in Oil Storage Tank and Oil Pipe Transportation, International Conference on Environment Impacts of the Oil and Gas Industries (EIOGI), Iraq, 2017, (DOI No: 10.1109/EIOGI.2017.8267629).

[29] R. Kannan, P. Selvan and P. R. Muralidharan. (1993). Field Experience on Improving Corrosion Performance of $\mathrm{OH}$ Lines Crossarms and Concrete Poles," 12th International Conference on Electricity Distribution, 1993. CIRED, Birmingham, UK, 1993, vol 3, (pp. 3.2/13.2/5).

[30] M. M. Caruso, D. A. Delafuente, V. Sottos, N. R. Moore and J.S. White. (2007). Solvent Promoted Self-Healing Epoxy Material, Macromolecules, 2007, Vol. 40, (pp. 8830-8832).

[31] P. A. Sorensen, S. Kiil, K. Dam-Johansen, and C. E. Weinell. (2009). Anticorrosive Coatings: A Review," Journal of Coating Technology and Research, 2009, Vol. 6, no. 2, (pp. 135-176). 